\title{
KAJIAN MENGENAI KAMPUNG BATIK SEBAGAI PEREMAJAAN KEMBALI KAMPUNG DI KAWASAN KARET KUNINGAN
}

\author{
Steven Wijaya ${ }^{1)}$, Timmy Setiawan ${ }^{21}$ \\ 1) Program Studi S1, Fakultas Teknik, Universitas Tarumanagara, stevenwijaya1996@gmail.com \\ 2) Program Studi S1, Fakultas Teknik, Universitas Tarumanagara, timmy@unitricipta.com
}

\begin{abstract}
Abstrak
Generasi milenial menjadi topik penting dalam berbagai diskusi di awal abad 21, kerana jumlah populasinya yang tengah berada di usia produktif dan memiliki jumlah terbesar secara global. Namun, awal generasi milenial di Indonesia dimulai dengan krisis moneter tahun 1998, dimana hal ini akan berpengaruh terhadap menurunnya tingkat pendidikan generasi milenial awal di Indonesia. Pendidikan dan perekonomian yang rendah membuat daya saing sumber daya manusia di beberapa daerah juga menurun, dalam kasus ini akan difokuskan pada kehidupan perkampungan di Kota Jakarta, dimana perbedaan kehidupan sangat-lah kontras antara yang memperoleh pendidikan tinggi dengan yang memperoleh pendidikan rendah (daerah perkampungan). Sehingga yang menjadi pertanyaan adalah bagaimana cara generasi melenial yang hidup di perkampungan kota Jakarta dapat bersaing dan bagaimana meremajakan kembali perkampungan di perkotaan khususnya Jakarta, agar generasi milenial di perkampungan tersebut dapat bersaing dan beradaptasi dalam generasi selanjutanya? Setiap perkampungan pastinya memiliki ciri khas dan nilai sejarah yang tinggi. Seiring dangan perkembangan dan tuntutan zaman, ciri khas dan nilai sejarah dari kampung itu sering dilupakan oleh warganya, sehingga suatu kampung tidak lagi memiliki identitas yang dapat mereka banggakan. Maka diperlukalah program untuk memulihkan kembali ciri khas dari suatu kampung dengan mengajak warga dari kampung tersebut untuk turut terlibat di dalamannya, sehingga keunikan dan cirikhas itu bisa menjadi manfaat baik dalam segi ekonomi, kebudayaan, dan sumber daya manusia di kampung tersebut. Dengan cara inilah kedudukan kampung ditengah kota dapat tetap bertahan dengan memberikan dampak positif bagi penghuni yang ada didalam kampung tersebut maupun dengan orang-orang luar yang ada di sekitarnya. Sehingga dengan menonjolkan sebuah cirikhas, generasi milenial yang tinggal di kampung tersebut dapat bersaing dan tetap dapat mempertahankan eksistensinya.
\end{abstract}

Kata kunci: eksistensi; generasi milenial; kampung kota

\begin{abstract}
Millennials have become an important topic in various discussions at the beginning of the 21st century with a population that is currently in productive age and has a greater global number. However, the beginning of the millennial generation in Indonesia began with the 1998 crisis, where this will affect the decline in the level of education of the early millennial generation in Indonesia. Education and a low economy make the competitiveness of human resources in some regions, in this case it will increase in the lives of villages in the city of Jakarta, where the difference in life is very contrasting between those who get higher education and those who get low education (in rural areas). So the question is how can the generation of melenial living in the city of Jakarta compete and how to rejuvenate urban settlements, especially Jakarta, so that the millennial generation in the village can compete and adapt in the next generation? Every village must have its own characteristics and high historical value. As the development and recovery of the times, the characteristics and historical values of the village are often forgotten by the people, so the village no longer has an identity that they can be proud of. So the program was needed to restore the distinctive characteristics of a village by inviting residents from the village to be involved in it, so that the uniqueness and precision that could be of benefit both in terms of economy, development, and human resources in the village. In this way the position of the village in the middle of the city can remain by providing positive for the residents in the house with
\end{abstract}


outsiders around it. By raising the characteristic of the village, the millennial in the village can compete and still be able to maintain its existence.

Keywords: existence; millennial generation; urban village

\section{PENDAHULUAN}

Generasi milenial atau generasi Y yang lahir Antara tahun 1981-1996 akan menjadi topik penting dalam berbagai diskusi di awal abad 21 ini karena jumlah populasinya yang tengah berada di usia produktif dan memiliki jumlah terbesar secara global. Generasi milenial juga memiliki tingkat pendidikan yang lebih tinggi dari generasi-generasi sebelumnya. Dengan kata lain generasi milenial memiliki signifikansi yang besar dan dapat membawa perubahan terhadap dunia.

Untuk lebih mengenal perutumbuhan generasi milenial di Indonesia ada baiknya bila kita mengingat kembali masal lalu yang terjadi di negeri ini. Pada tahun 1998, Indonesia mengalami suatu tragedi besar yang tidak bisa kita lupakan yaitu, krisis moneter. Kemrosotan ini menyebabkan tingkat pengangguran, kriminalitas, dan angka putus sekolah yang tinggi. Generasi milenial yang masih berusia remaja dan menduduki pendidikan di tingkat SMP dan SMA terpaksa berhenti sekolah dan menjadi kuli serabutan untuk dapat bertahan hidup mengatasi kondisi ekonomi yang sulit. Kondisi yang lebih parah terletak di daerah-daerah perkampungan yang secara finansial memang sudah hidup dalam kesederhanaannya. Generasi milenial di daerah perkampungan inilah yang akan kesulitan untuk bersaing di dunia kerja yang sudah memasuki era digital. Mereka harus cepat menyesuaikan diri dan mengasah bakatnya untuk dapat bersaing dan meraih cita-cita yang ingin mereka capai, tidak hanya sekedar mengandalkan lowongan kerja dari gedung-gedung di sekeliling tempat tinggal mereka yang hanya dapat memperkerjakan mereka sebagai staf pembersih dan penjaga toko yang nantinya akan mulai ditinggalkan dan gigantikan oleh sistem yang berteknologi canggih dan serba instan.

Selain nilai produktifitas sumber daya manusia yang kurang, aktifitas perkembangan perkotaan yang cepat dan berat sebelah tangan membuat identitas sebuah kampung juga semakin memudar. Kampung di perkotaan tidak lagi memiliki ciri khas yang dapat mereka tonjolkan, padahal bila dilihat dari asal muasalnya setiap kampung memiliki ciri khas dan budaya yang unik. Oleh sebab itu perlu adanya upaya untuk meremajakan kembali kehidupan perkampungan yang berada di pusat kota untuk meningkatkan nilai produktifitas sumber daya manusia dan memunculkan kembali identitas sebuah kampung agar tetap dikenal dan dipandang baik oleh masyarakat sekitar di generasi milenial.

Terlepas dari itu yang mejadi pertanyaan disini adalah bagaimana cara generasi melenial yang hidup di perkampungan kota Jakarta dapat bersaing dan bagaimana meremajakan kembali perkampungan di perkotaan khususnya Jakarta, agar generasi milenial di perkampungan tersebut dapat bersaing dan beradaptasi dalam generasi selanjutanya. Maka untuk menjawab pertanyaan tersebut perlu dipelajari lebih dalam mengenai karakteristik generasi milenial dan ciri khas yang ada dalam suatu kampung di perkotaan. Disisi lain pemilihan lokasi perancangan juga menjadi faktor penting untuk menerapkan pemikiran dalam menciptakan kehidupan perkampungan di ruang kota yang ada, sebab setiap daerah memiliki ciri khasnya masing-masing. Berikut merupakan identifikasi masalah dalam penelitian ini:

- Tingkat pendidikan generasi milenial di daerah perkampungan masih relatif rendah.

- Perkembangan kota yang cepat dan kurangnya perhatian pemerintah menyebabkan ciri khas dan nilai sejarah yang ada di dalam perkampungan hilang.

- Semakin terbatasnya lahan menyebabkan permukinan perkampungan di kota semakin padat dan tidak layak huni sehingga mempengaruhi kesehatan, keamanan, dan produktifitas penghuninya. 
Batasan penelitian terfokus pada permasalahn lingkungan perkampungan untuk kaum milenial di Kota Jakarta dan akan diselesaikan dalam wujud rancangan arsitektural yang dapat menjawab kebutuhan mereka. Agar generasi milenial yang hidup di pekampungan kota dapat bersaing dan beradaptasi pada perkembangan zaman.

\section{KAJIAN LITERATUR}

\section{Pengaruh Krisis Moneter 1998 Terhadap Generasi Milenial}

Pada tahun 1998 krisis ekonomi melanda Indonesia. Kondisi perekonomian bangsa Indonesia porak poranda, karena basis ekonomi yang rapuh. Dan pada waktu itu pula generasi milenial sedang dalam usia remaja sampai usia produktif untuk melanjutkan pendidikan ke dalam jenjang sarjanah. Dampak dari bangkrutnya perusahaan, banyak tenaga kerja yang kehilangan pekerjaanya (generasi $\mathrm{x}$ ). PHK dilakukan oleh beberapa perusahaan dalam rangka efisiensi agar produksi tetap berjalan. Di sisi lain pencari kerja baru bermunculan ikut bertanding dalam memperebutkan lapangan kerja (generasi y yang putus sekolah). Dengan demikian jumlah pengangguran meningkat secara tajam, sebagai akibat PHK dan angkatan kerja baru. Sementara daya serap lapangan kerja sangat minim karena tidak adanya pembukaan usaha baru. Dengan meningkatnya pengangguran dan sulitnya memenuhi kebutuhan hidup di waktu itu banyak generasi x yang menjadi orang tua generasi milenial pada waktu itu tidak mampu lagi menyekolahkan anaknya (generasi y) ke jenjang berikutnya.

Dari meningkatnya angka pengangguran tersebut, ternyata masih ada beberapa lowongan pekerjaan yang tidak terisi. Lowongan tersebut tidak dapat terisi karena adanya tuntutan keahlian, ketrampilan, dan keprofesionalan yang kurang dimiliki oleh tenaga kerja lulusan lembaga pendidikan Indonesia. Berdasarkan tabel di bawah ini pelajar yang mamasuki sekolah kejuruan memiliki tingkat pengangguran yang lebih sedikit bila dibandingkan dengan SMA yang berada di posisi tertinggi dalam angka pengangguran. Hal ini dikarenakan pelajar yang masuk SMK langsung memiliki kejuruan dan keahlian khusus dibandingkan dengan SMA, sehingga lebih banyak perusahaan yang ingin menerimanya.

Namun dalam perkembangan berikutnya angka pengangguran tertinggi masih didominasi dengan tingkat SMA, penulis mengambil data tahun 2013 dan 2014 sebab pada tahun itu merupakan generasi milenial yang lahir pada tahun 1995-1996 dimana dalam teori yang ada merupakan tahun kelahiran terakhir dari generasi milenial dan hampir sebagian besar tingkat pendidikan yang rendah ditemui di daerah-daerah perkampungan yang memiliki penghasilan yang rendah. Dalam kasus ini penulis memfokuskan pada daerah perkampungan di Kota Jakarta.

Tabel 1. Struktur Penganguran Menurut Tingkat Pendidikan (persen)

\begin{tabular}{|l|r|r|r|}
\hline \multicolumn{1}{|c|}{ Pendidikan } & 1982 & 1995 & 1998 \\
\hline SD ke bawah & 61.74 & 40.68 & 23.09 \\
SLTP & 11.79 & 16.33 & 19.44 \\
SLTA Umum & 12.30 & 24.90 & 32.13 \\
SLTA Kejuruan & 12.69 & 11.61 & 16.86 \\
Diploma & 0.91 & 2.61 & 3.47 \\
- Diploma I & & 0.74 & 0.94 \\
- Diploma II & & 1.87 & 2.53 \\
Universitas & 0.57 & 3.86 & 5.02 \\
\hline
\end{tabular}

Sumber: Statistik Tahunan Indonesia, 1985, 1995, 1998 
Tabel 2. Tingkat Pengangguran Terbuka (TPT) menurut Pendidikan (Persen)

\begin{tabular}{|c|c|c|c|c|}
\hline \multirow{2}{*}{$\begin{array}{c}\text { Pendidikan Tertinggi yang } \\
\text { Ditamatkan }\end{array}$} & \multicolumn{2}{|c|}{2013} & \multicolumn{2}{|c|}{2014} \\
\hline & Februari & Agustus & Februari & Agustus \\
\hline (1) & (2) & (3) & (4) & (5) \\
\hline SD Ke bawah & 3,55 & 3,44 & 3,69 & 3,04 \\
\hline Sekolah Menengah Pertama & 8,21 & 7,59 & 7,44 & 7,15 \\
\hline Sekolah Menengah Atas & 9,45 & 9,72 & 9,10 & 9,55 \\
\hline Sekolah Menengah Kejuruan & 7,72 & 11,21 & 7,21 & 11,24 \\
\hline Diploma I/II/III & 5,72 & 5,95 & 5,87 & 6,14 \\
\hline Universitas & 5,02 & 5,39 & 4,31 & 5,65 \\
\hline Total & 5,88 & 6,17 & 5,70 & 5,94 \\
\hline
\end{tabular}

Sumber: BPS, Diolah dari Sakernas 2013, 2014

\section{Hilangnya Identitas Kampung}

Dari hasil perolehan data mengenai tingkat pendidikan yang telah penulis cari, dapat disimpulkan bahwa kurangnya perhatian pemerintah terhadap daerah-daerah yang memiliki tingkat perekonomian yang rendah, dalam kasus ini daerah perkampungan di Kota Jakarta. Sebab faktor ekonomi dapat menentukan tingkat pendidikan. Begitu pun juga sebaliknya, tanpa adanya pengetahuan yang mapan seseorang akan sulit untuk bersaing dalam dunia kerja. Terlebih lagi perkembangan dan persaingan dalam dunia kerja di Jakarta semakin ketat dengan banyaknya SDM asing yang memiliki kemampuan lebih unggul. Selain itu Pertumbuhan dan perkembangan pembangunan di Jakarta sangatlah cepat terlebih lagi keputusan pemerintah yang lebih berpihak kepada swasta (pembangun) yang dengan mudahnya menggusur perkampungan tanpa memikirkan dampak kedepannya. Di beberapa tempat memang sudah dijanjikan dengan dibuatkan rusun yang layak huni namun lagi-lagi hal itu gagal. Sebab untuk meremajakan kembali perkampungan perlu memahami modal sosial dan fleksibelitas warga kampung.

Modal sosial berfungsi membuat sebuah keluarga mendapat modal untuk membuka usaha, memberikan akses pada barang dan jasa murah, atau informasi khusus terkait peluang mendapatkan pekerjaan di sektor informal, dan hal-hal lain yang penting bagi keberlanjutan pemasukan warga kampung. Faktor modal sosial jarang sekali dipertimbangkan dalam kebijakan relokasi ke rumah susun. Sedangkan fleksibilitas, merujuk pada keluwesan warga kampung yang memungkinkan mereka bermanuver di tengah keterbatasan. Dalam konteks tenaga kerja, bisa disebut pekerja serabutan-hari ini sopir tembak, besoknya nukang di rumah tetangga, sementara lusa jadi kuli panggul pelabuhan. Di perkampungan sering kali kita menjumpai ibu-ibu memasak sekaligus menjual gorengan di gang yang agak lebar dengan jam operasional yang menyesuaikan kebutuhan pelanggan. Rumah-rumah di kampung itu bukan hanya berfungsi sebagai tempat istirahat tapi juga ruang ekonomi untuk membuat pernakpernik yang dapat mereka jual. Hal ini juga membuat komunikasi dengan sesama tetangga berjalan dengan baik, sehingga fleksibilitas dan modal sosial tidak bisa dipisahkan. Fleksibilitas ini tidak akan bisa ditemui di rumah susun yang umumnya punya regulasi ketat.

Untuk mengetahui modal sosial dan fleksibelitas yang cocok untuk suatu perkampungan perlu pemahaman lebih mengenai asal mula, sejarah, dan aktivitas warga yang ada di kampung tersebut. Jadi modal sosial dan fleksibelitas suatu kampung berbeda-beda bila dibandingkan dengan kampung yang lain. Oleh karena itu dalam merelokasi dan melakukan peremajaan kembali suatu perkampungan perlu dipelajari sejarah dan aktivitas warganya sebab setiap kampung memiliki ciri khas dan keunikannya masing-masing dan dari keunikan itulah yang 
harus kita ambil sebagai acuan dalam menentukan modal usaha dan fleksibelitas dalam program kampung yang baru.Itulah sebabnya mengapa keberadaan perkampungan di Jakarta semakin tersingkirkan dan kehilangan identitasnya.

\section{Kualitas dan Karakteristik Permukiman Kampung}

Tanpa adanya upaya pemerintah untuk meremajakan kembali perkampungan akan meningkatkan kepadatan di daerah perkampungan, sebab hal ini berkaitan langsung mengenai keterbatasan lahan dan penggusuran yang dilakukan pihak swasta terhadap daerah perkampungan dengan cepatnya pertmbuhan penduduk di daerah tersebut. Hal ini kemudian memicu tingginya tingkat kepadatan di daerah perkampungan kota yang menyebabkan daerah tersebut menjadi kumuh dan tidak layak huni.

Bangunan secara bertahap dikembangkan di sekitar bangunan lama. Hasilnya sebagian besar merupakan perpaduan antara struktur lama dan baru. Beberapa bangunan adalah sisasisa periode yang lebih tua, sementara yang lain baru-baru ini direnovasi atau sepenuhnya dibangun kembali. Penduduk sering menambahkan ekstensi bangunan yang terjadi tidak hanya karena tekanan langsung dari pertumbuhan keluarga, tetapi juga ketika keluarga memperoleh beberapa sumber dana tambahan.

Bagi penghuninya, kampung mewakili lebih dari sekadar ruang untuk hidup; ia menawarkan keamanan dan stabilitas. Kent (1990) menunjukkan bahwa rumah tidak dapat dilihat secara terpisah dari pemukiman, tetapi harus dilihat sebagai bagian dari sistem sosial dan tata ruang total yang berhubungan dengan cara hidup pemukiman tertentu. Tidak seperti rumah petak vertikal perkotaan, pengaturan morfologis kampung menawarkan beberapa keuntungan. Karena tidak ada aturan formal dan atau perbedaan kaku antara ruang pribadi dan nonpribadi, sangat normal bagi penghuni untuk menggunakan ruang tersebut segera di luar rumah mereka untuk mencuci, menyimpan barang-barang, memasak, menyiapkan makanan, dan makan makanan. Hidup bersama sebagai komunitas penghuni memastikan meninggalkan pintu dan jendela mereka terbuka. Visibilitas tinggi ke dalam dan ke luar memberi tetangga banyak peluang untuk berinteraksi dan mengobrol. Karena semua orang tahu bisnis orang lain, tidak perlu ikut campur dan penghuni bisa hidup bersama dalam semangat saling percaya.

Berdasarkan hasil survei yang dilakukan oleh International Journal of Architectural Research, 2016 Archnet-IJAR, 22,4\% rumah memiliki luas di kisaran 11-20 m2, 23,4\% memiliki luas di kisaran 21-30m2, 7,5\% memiliki luas di kisaran 31-40m2, 14,0\% memiliki luas dalam kisaran 41-50m2, dan sisanya ditemukan didistribusikan secara acak antara 50 dan 100m2. Luas lantai rata-rata adalah $23,5 \mathrm{~m} 2$. Perbandingan antara luas lantai dan jumlah rata-rata individu, dengan rata-rata konsumsi kamar per orang menunjukkan nilai 5,98m2 / orang, menunjukkan bahwa penghuni kampung memiliki ruang hidup yang tidak memadai, jika dibandingkan dengan Standar Nasional Indonesia 9m2 / orang. Selain itu dalam survey tersebut perumahan kampung dikategorikan menjadi 4, yaitu:

- Shelter.

Hunian yang sempit dan tidak memiliki ruang basah (dapur dan toilet). Jenis hunian itu muncul dikarenakan semakin padatnya suatu permukiman mengenai keterbatasan lahan. Hunian ini merupakan jenis hunian baru dan bukan merupakan tipe dasar dari hunian perkampungan.

- Rumah Umum

Kategori rumah ini merupakan yang paling sering dijumpai di daerah perkampungan kota, sudah ada ketersediaan ruang untuk kegiatan sehari-hari dan sudah tersedia area basah (toilet dan dapur). Namun penataan dan sirkulasi dalam ruang masih tidak baik.

- Rumah Sebagai Sumber Penghasilan Menampung kegiatan yang menghasilkan pendapatan seperti warung, warteg, kamar sewa (kostan), dan produksi usaha kecil.

- Rumah Ideal 
Kategori rumah yang sudah ada ketersediaan ruang untuk kegiatan sehari-hari dan sudah tersedia area basah (toilet dan dapur). Penataan ruang dan sirkulasi dalam ruang juga sudah terorganisir dengan baik.

Tabel 3. Tipe dan Kategori Hunian Kampung Kota

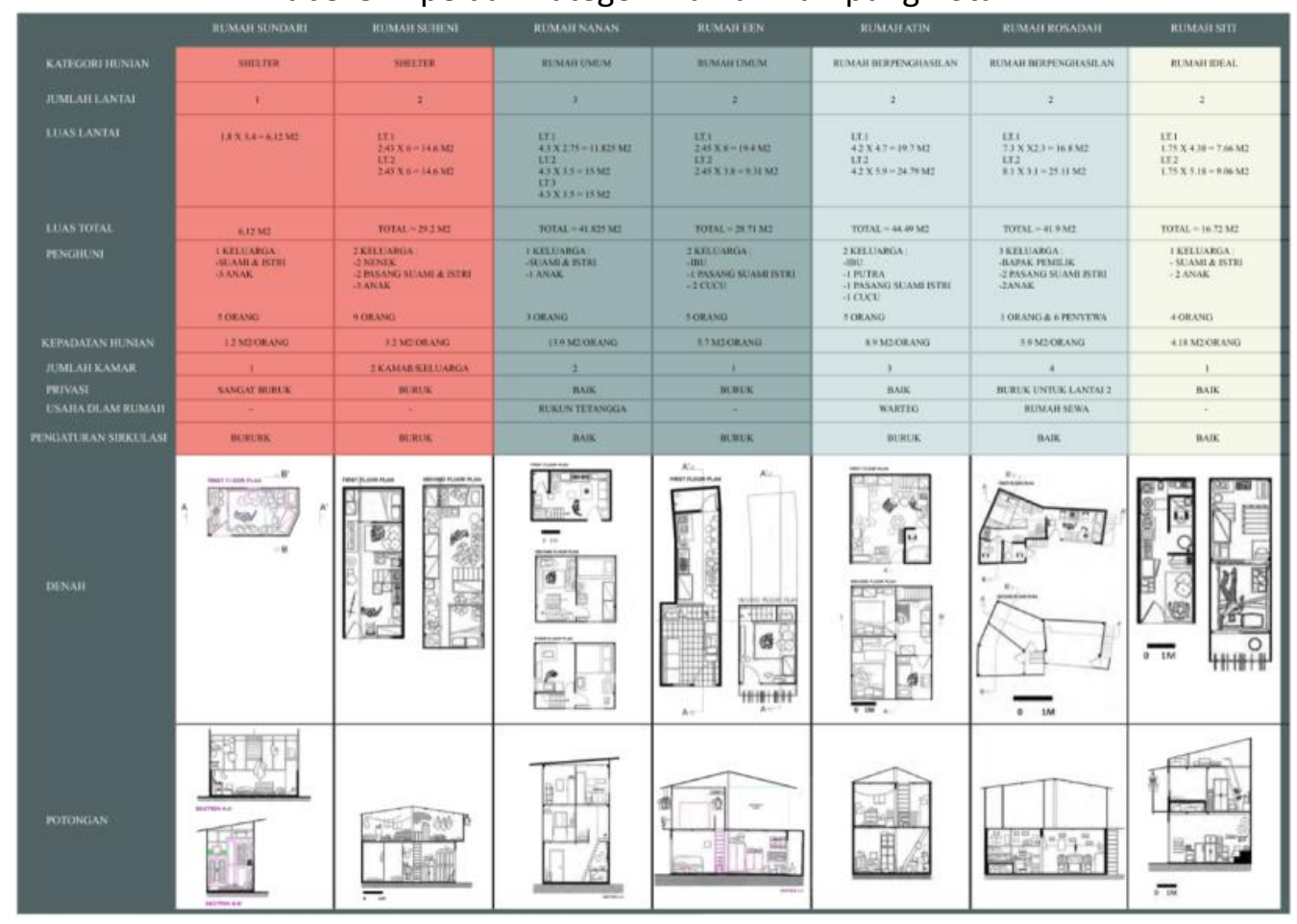

Sumber: Archnet-IJAR, 2016

\section{METODE}

\section{Metode Pengumpulan Data}

Pengumpulan data dalam perancangan ini ada dua macam, yaitu data primer dan data sekunder. Dalam pengumpulan data dari informasi primer dan sekunder, digunakan metode yang dapat dijelaskan sebagai berikut:

\section{Data Primer}

Dengan melakukan pengamatan terhadap hal-hal penting secara langsung terhadap objek dan masalah yang ada. Dalam kasus ini penulis melakukan survey lapangan secara langsung terhadap tapak yang ingin dipilih. Berikut merupakan data yang didapat dalam hasil survey:

- Mencari lokasi perkampungan di tengah-tengah pusat kota

- Mengamati kualitas dan aktivitas di perkampungan dan daerah sekitarnya

- Mencari sejarah dan keunikan di daerah tersebut

- Mendata transportasi akses untuk mencapai lokasi

\section{Data Sekunder}

Merupakan data yang diperoleh dari literature atau bersumber secara tidak langsung. Dalam perancangan ini pencarian data sekunder penulis lakukan dengan mencari studi pustaka sebagai berikut:

- Mencari studi mengenai tipe dan perilaku generasi milenial

- Pengaruh krisis moneter 1998 terhadap generasi milenila

- Mencari studi mengenai tingkat pendidikan generasi milenial di perkampungan kota

- Mencari tipe dan perilaku hunian perkamungan kota

- Mencari sejarah dan keunikan perkembangan perkampungan kota yang telah dipilih lokasinya 


\section{Metode Perancangan}

Metode perancangan yang digunakan dalam proyek Kampung Batik ini penggunakan metode Everyday Urbanism. Metode everyday urbanism merupakan konsep yang diperkenalkan oleh Margaret Crawford, John Chase dan John Kaliski pada tahun 1999. Sebuah pendekatan untuk menemukan makna dalam kehidupan sehari-hari yang memperkuat situasi yang sering tidak diperhatikan dan dialami yang terjadi dalam kehidupan sehari-hari.

Everyday Urbanism juga dapat dianggap sebagai metode dengan pertimbangan multidimensi dari berbagai respons terhadap waktu dan tempat tertentu. Sebagai contoh, nilai-nilai ruang publik dan kehidupan masyarakat dipenuhi dengan pasar jalanan dan pedagang kaki lima yang dibuat secara organik, dalam metode ini munculnya suatu aktivitas yang terbentuk dengan sendirinya merupakan suatu keuntungan dan dapat menjadi nilai positive bagi perancangan daerah tersebut.

Penentuan Ciri Khas Kampung dan Program

Ciri khas kampung didapat berdasarkan pengumpulan data melalui sejarah di daerah perkampungan, juga dengan melakukan survey ke kawasan di sekitar kampung tersebut. Dalam kasus ini penulis membandingkan dan mencari apakah masih terdapat persamaan dari keunikan kegiatan di masa lalu dengan yang ada sekarang ini. Kemudian dari hasil pencarian dan pengamatan tersebut penulis mendapatkan ciri khas dari kampung tersebut yang akan dijadikan sebagai kegiatan utama dalam program perancangan. Kemudian penulis mengamati dan mencari lagi kegiatan-kegiatan lain yang mendukung ciri khas tersebut.
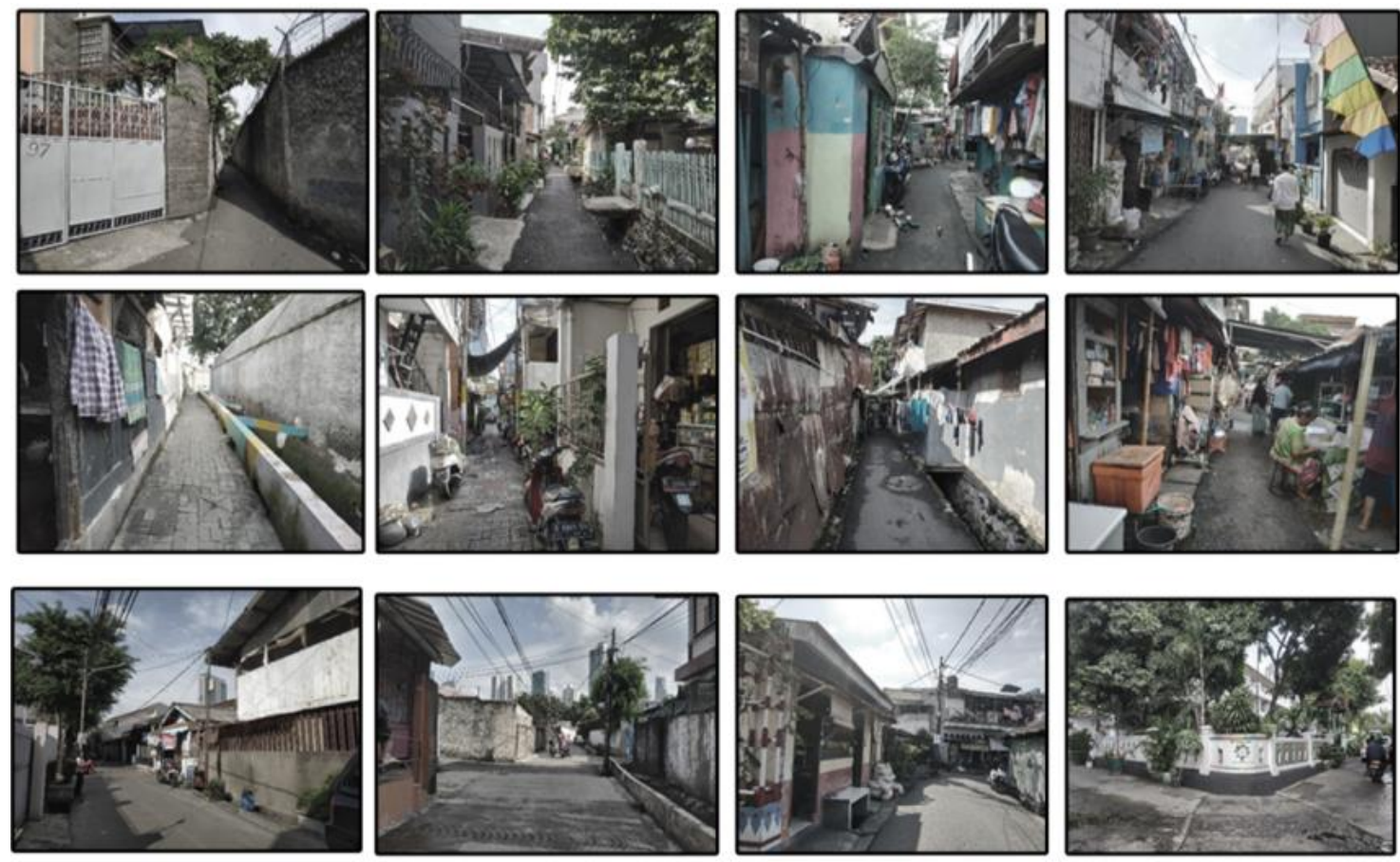

Gambar 1. Foto Tinjauan Lokasi Sumber: Penulis, 2019 


\section{DISKUSI DAN HASIL}

\section{Pemilihan Lokasi}

Pemilihan lokasi perancangan terletak di puat SCBD daerah Karet Kuningan. Lokasi ini dipilih karena kampung di daerah Karet Kuningan terletak di pusat kota dan diapit oleh SCBD di Jakarta, dimana perbedaan Antara Kampung dan lingkungan sekitarnya sangatlah kontras. Selain itu dengan pesatnya perkembangan di daerah ini membuat keberadaan kampung Karet semakin tersingkirkan dan kehilangan existensinya di kalangan masyarakat. Saat ini penduduk kampung Karet hanya mengandalkan bangunan-bangunan pencakar langit di sekitarnya sebagai jasa pelayanan yang merupakan mata pencaharian tetap mereka, namun hal ini akan dipersulit dengan mulai masuknya sistem pelayanan digital yang akan menggantikan posisi mereka.

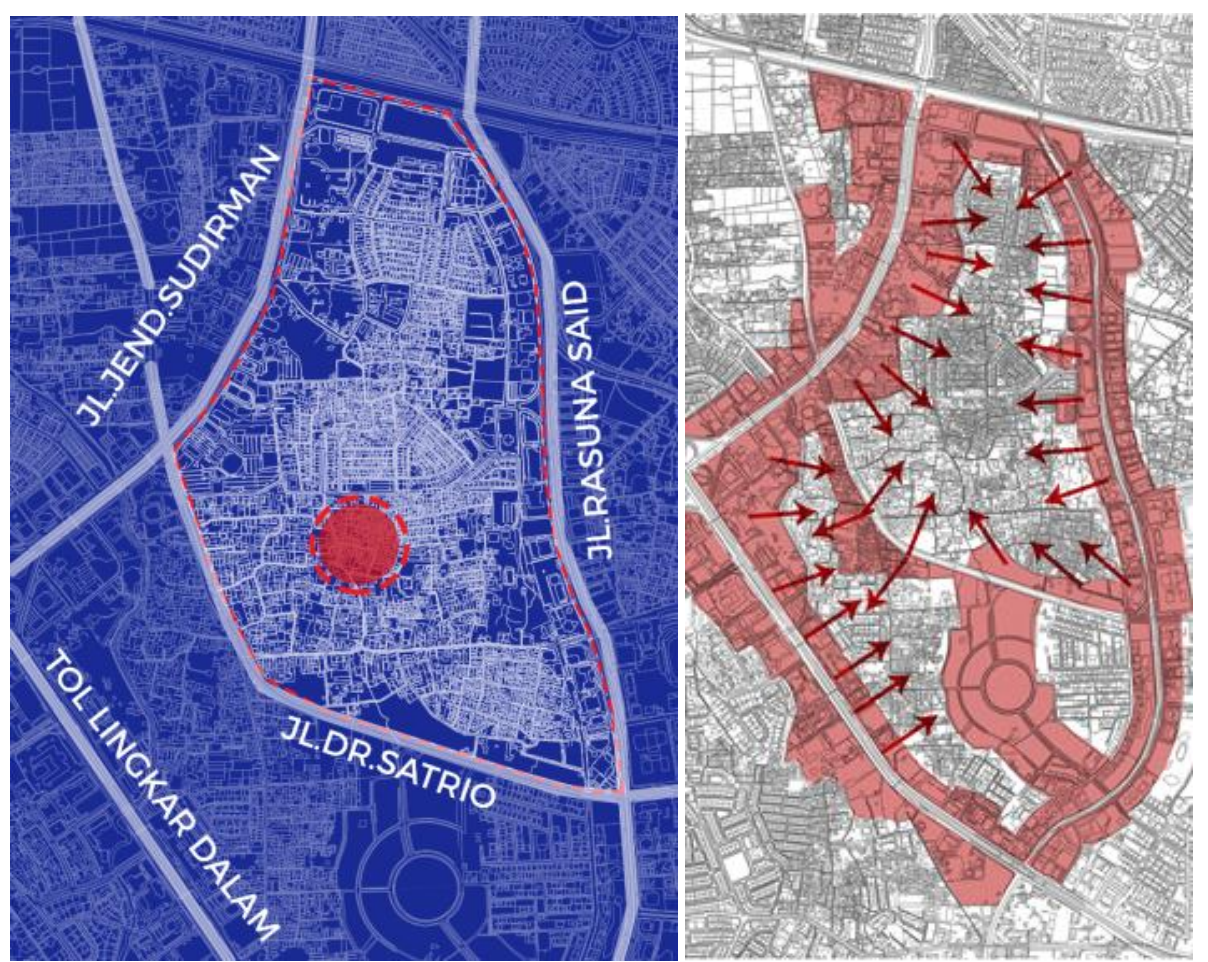

Gambar 2. Peta Lokasi

Sumber: Penulis, 2019

\section{Sejarah Lokasi}

Untuk mengenal lebih dalam mengenai Kampung ini penulis mencari data mengenai sejarah dan perkembangan di daerah tersebut. Ternyata Kawasan Karet Kuningan merupakan kantung permukiman "historis" kampung Betawi di tepi sungai Krukut yang menjadi saksi perkembangan masa lalu kota Jakarta. Kedatangan Pangeran Kuningan bersamaan pasukan Pangeran Fatahillah yang kemudian menaklukkan Sunda Kelapa. Dari kisah tersebut, menunjukkan bahwa kampung ini merupakan kampung tua dan wilayah yang dinamakan kampung Kuningan sebenarnya sangat luas mencakup Kelurahan Kuningan Timur, Kuningan Barat dan sebagian Karet Kuningan. Keberadaan kampung ini menjadi unik karena berada di lingkungan modern namun demikian wajah dan budaya kampung masih tersisa, ruang-ruang yang secara fisik menunjukkan karakter kampung masih bertahan di tengah metropolitan.

Sejalan dengan perkembangan waktu Karet Kuningan dan Karet Semanggi menjadi salah satu sentra pabrik atau usaha batik yang dikelola secara tradisional. Menurut kliping berita Kompas, pabrik batik di kawasan ini sudah beroperasi sejak 1910. Sejalan dengan perkembangan kota, kawasan pabrik batik di DKI Jakarta mulai dipadati penduduk. Keberadaan pabrik-pabrik batik di wilayah permukiman itu mulai menimbulkan masalah bagi lingkungan. 
Selain itu, dalam Rencana Umum Tata Ruang DKI Jakarta1985-2005, peruntukan kawasan Karet, Setiabudi, dan Kuningan, yang sebelumnya terkenal sebagai sentra perbatikan, ditetapkan sebagai permukiman dan perkantoran. Kawasan itu kini termasuk dalam area "segitiga emas" sehingga industri kecil di sana harus beralih ke kawasan industri. Para pemilik pabrik dan masyarakat yang memiliki modal banyak mengubah pabriknya yang luas untuk dijadikan sebagai hunian atau kos-kosan yang banyak dicari untuk para pekerja kantoran sedangkan. Namun masih banyak pula bangunan-bangunan bekas pabrik tersebut yang masih beridi hinga saat ini.

Dari pendataan mengenai sejarah dan kegiatan di kawasan tersebut, maka Batik dijadikan sebagai acuan untuk program utama dalam perancangan yang akan dijadikan sebagai ciri khas dan keunikan di daerah Kampung Karet Kuningan.

Untuk mengenal lebih dalam mengenai Kampung ini penulis mencari data mengenai sejarah dan perkembangan di daerah tersebut. Ternyata Kawasan Karet Kuningan merupakan kantung permukiman "historis" kampung Betawi di tepi sungai Krukut yang menjadi saksi perkembangan masa lalu kota Jakarta. Kedatangan Pangeran Kuningan bersamaan pasukan Pangeran Fatahillah yang kemudian menaklukkan Sunda Kelapa. Dari kisah tersebut, menunjukkan bahwa kampung ini merupakan kampung tua dan wilayah yang dinamakan kampung Kuningan sebenarnya sangat luas mencakup Kelurahan Kuningan Timur, Kuningan Barat dan sebagian Karet Kuningan. Keberadaan kampung ini menjadi unik karena berada di lingkungan modern namun demikian wajah dan budaya kampung masih tersisa, ruang-ruang yang secara fisik menunjukkan karakter kampung masih bertahan di tengah metropolitan.

Sejalan dengan perkembangan waktu Karet Kuningan dan Karet Semanggi menjadi salah satu sentra pabrik atau usaha batik yang dikelola secara tradisional. Menurut kliping berita Kompas, pabrik batik di kawasan ini sudah beroperasi sejak 1910. Sejalan dengan perkembangan kota, kawasan pabrik batik di DKI Jakarta mulai dipadati penduduk. Keberadaan pabrik-pabrik batik di wilayah permukiman itu mulai menimbulkan masalah bagi lingkungan. Selain itu, dalam Rencana Umum Tata Ruang DKI Jakarta1985-2005, peruntukan kawasan Karet, Setiabudi, dan Kuningan, yang sebelumnya terkenal sebagai sentra perbatikan, ditetapkan sebagai permukiman dan perkantoran. Kawasan itu kini termasuk dalam area "segitiga emas" sehingga industri kecil di sana harus beralih ke kawasan industri. Para pemilik pabrik dan masyarakat yang memiliki modal banyak mengubah pabriknya yang luas untuk dijadikan sebagai hunian atau kos-kosan yang banyak dicari untuk para pekerja kantoran sedangkan. Namun masih banyak pula bangunan-bangunan bekas pabrik tersebut yang masih beridi hinga saat ini.

Dari pendataan mengenai sejarah dan kegiatan di kawasan tersebut, maka Batik dijadikan sebagai acuan untuk program utama dalam perancangan yang akan dijadikan sebagai ciri khas dan keunikan di daerah Kampung Karet Kuningan. 


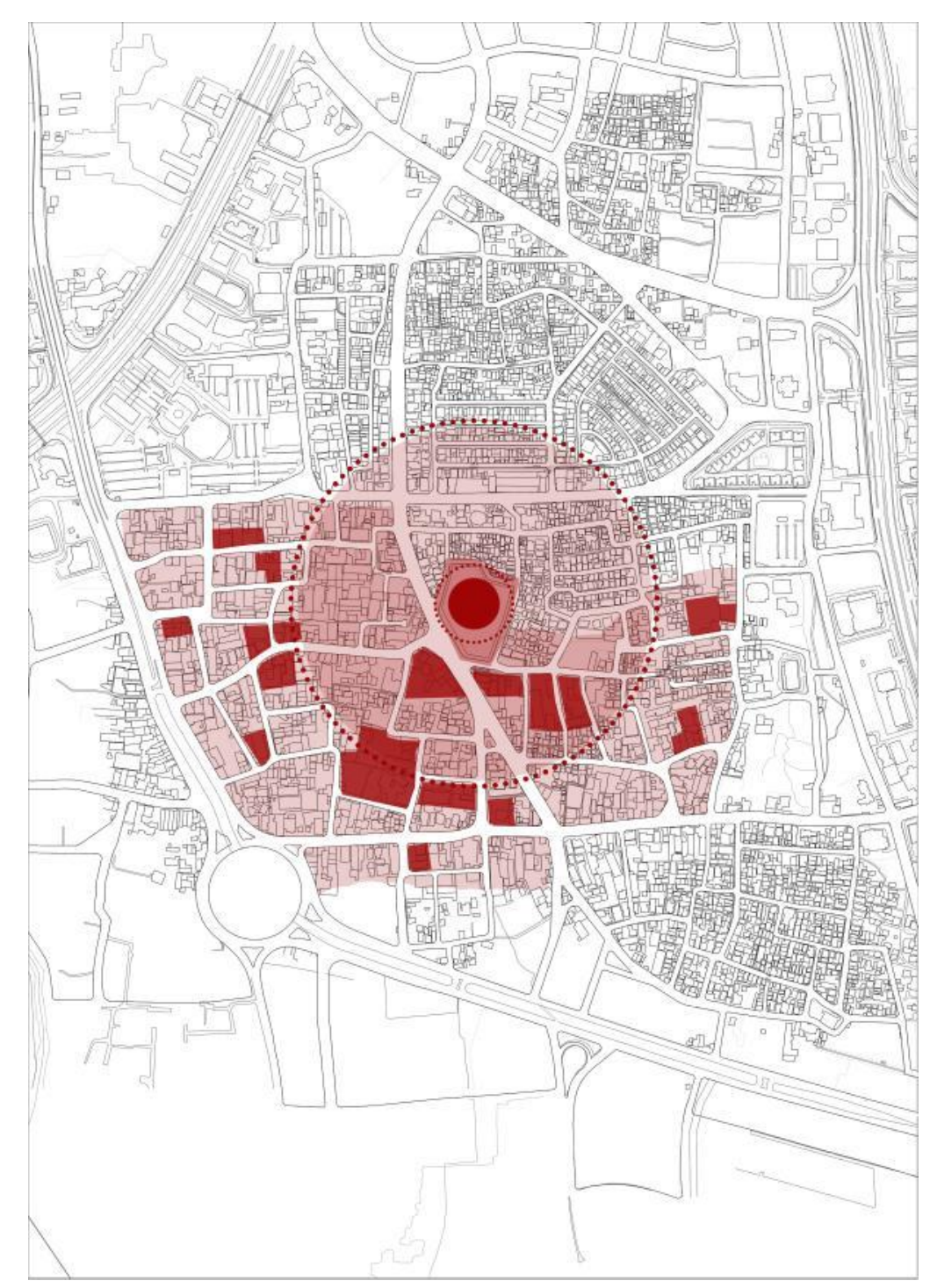

Gambar 3. Peta Persebaran ex-Pabrik Batik yang Masih Ada Sumber: Penulis, 2019

\section{Program}

Program bangunan yang didapat berdasarkan hasil pengamatan dan pengumpulan data mengenai sejarah dan aktivitas yang ada di kawasan Karet Kuningan, maka penulis menyimpulkan bahwa program Kampung Batik merupakan program yang cocok untuk diterapkan di daerah tersebut.

Kampung Batik ingin mengajak para pengusaha batik yang masih aktif di daerah tersebut berkerjasaman dengan warga kampung untuk memproduksi, memamerkan, dan memperkenalakan kembali filosofi batik kepada generasi milenial, sehingga selain berfungsi sebagai hunian, kampung ini bisa menjadi sarana wisata dan edukasi terhadap lingkungan sekitar juga meningkatkan perekonomian dan sumber daya manusia masyarakat kampung. 


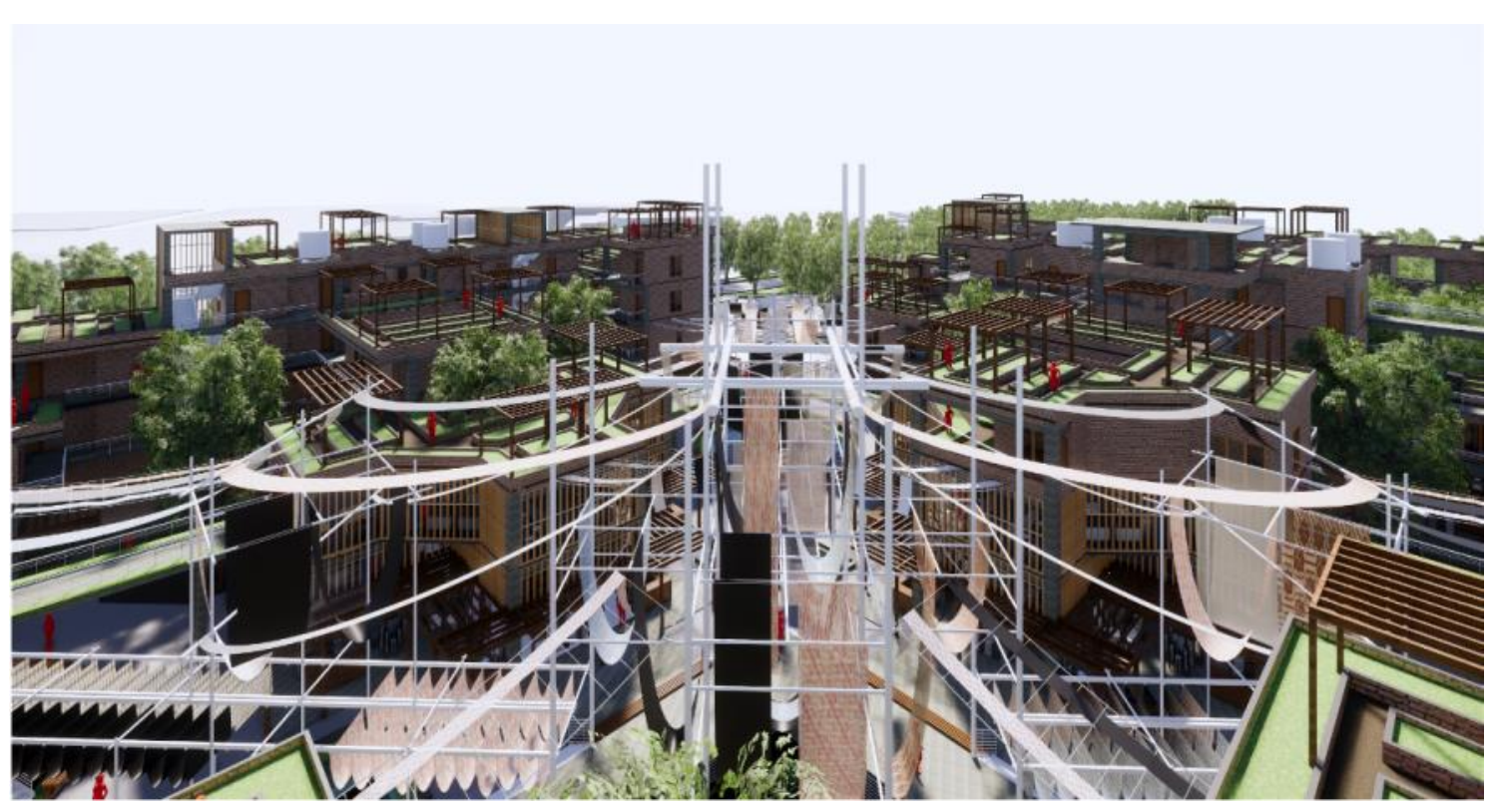

Gambar 4. Kampung Batik

Sumber: Penulis, 2019

Program Hunian pada Kampung Batik yang diajukan:

- Hunian ideal

Menciptakan Hunian yang memenuhi standar kenyamanan dan mengacu pada Sustainable Development Goals. Hunian terintegrasi dengan ruang terbuka hijau dimana memungkinkan untuk setiap ruang mendapatkan cahaya dan pengudaraan alami.

- Hunian + usaha

Dari Hasil penelitian lapangan, banyak warga kampung yang membuka usaha kuliner, pelayanan bersih-bersih, perdagangan kebutuhan pokok, sampai menyediakan kamar sewa, sehingga tipe rumah usaha menjadi sangat penting untuk meningkatkan perekonomian masyarakat kampung.

Program fasilitas usaha yang diajukan:

- Workshop Batik

Merupakan tempat pembuatan batik yang diolah secara tradisional dengan mengajak para pengusaha batik di sekitar perkampungan untuk bekerjasama dengan warga kampung yang tertarik dengan batik.Proses pembuatan batik pada proyek ini difokuskan pada tahapan tradisional atau batik tulis dan masih menggunakan bahanbahan pewarna alamai sehingga limbah yang dibuang tidak berbahaya bagi lingkungan.

- Galeri dan Pasar Batik

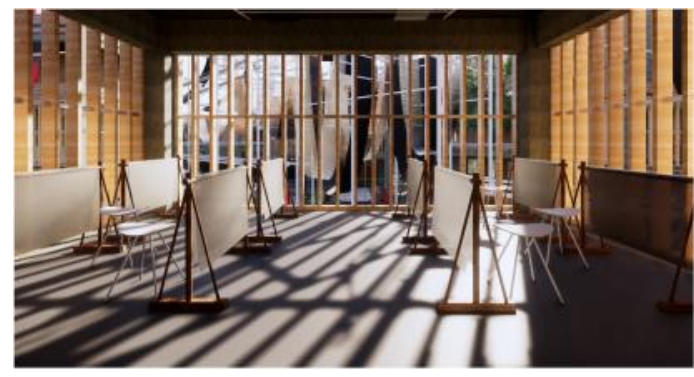

Gambar 5. Ruang Membatik

Sumber: Penulis, 2019 


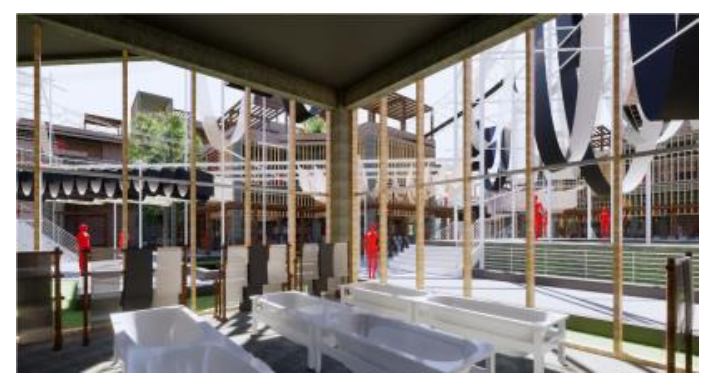

Gambar 6. Ruang Celup

Sumber: Penulis, 2019

Tempat untuk memamerkan karya-karya batik baik yang masih berupa kain sampai hasil olahan seperti pakaian dan kerajinan lainnya dari penghuni kampung batik untuk dipertunjukkan secara publik dan dapat diperjual belikan.

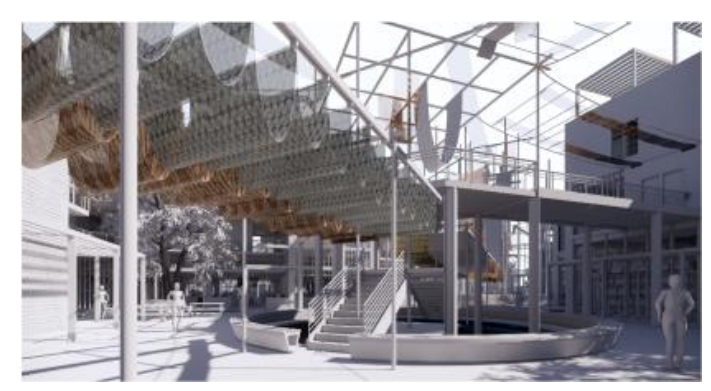

Gambar 7. Ruang Jemur Sumber: Penulis, 2019

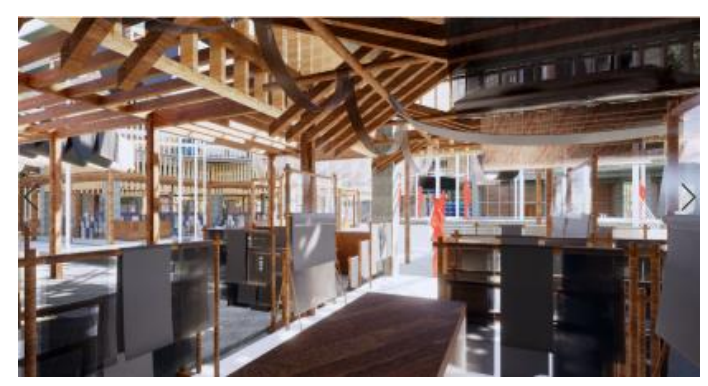

Gambar 8. Ruang Batik

Sumber: Penulis, 2019

- Pelatihan Batik dan Fashion

Untuk meningkatkan kualitas sumber daya manusia di Kampung Batik maka akan disediakan fasilitas edukasi berupa pelatihan membatik dan sekolah fashion. Sehingga dengan adanya edukasi dan bimbingan mengenai design ini akan meningkatkan kreatifitas dan kemampuan masyarakat kampung batik untuk dapat menghasilkan karya-karya yang baik dan berdaya saing tinggi. 


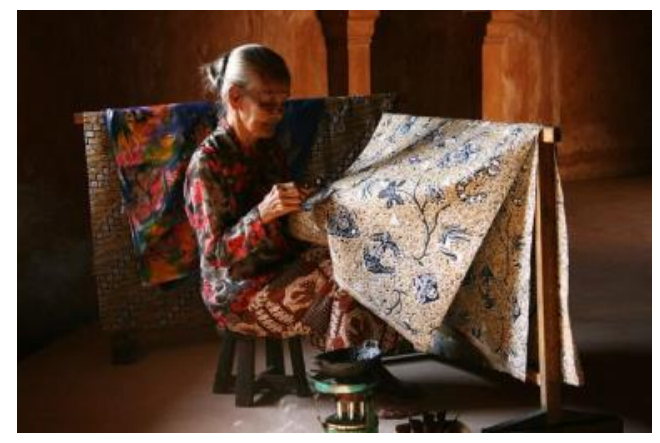

Gambar 9. Pelatihan Membatik

Sumber: https://pixels.com/featured/6-making-traditional-batik-rahmat-nugroho.html

\section{- Taman Warna}

Jenis vegetasi yang akan ditanam pada proyek ini akan lebih mengutamakan tanaman yang bisa menghasilkan pewarna alami untuk kain batik, diantaranya adalah pohon mengkudu, manggis, jambu biji, buah soga, daun indigo, kunyit, dan biji kesumba. Sehingga selain sebagai taman rekreasi juga dapat memberikan nilai edukasi terhadap warga sekitar terhadap bahan-bahan pewarna alami yang dapat di olah untuk dipakai sebagai bahan pewarna pakainan.

Kain dengan pewarnaan alami dari, batang, akar, daun, buah, dan biji-bijian yang ditanam di tapak tersebut membuat limbah yang dikeluarkan tidak berbahaya bagi lingkungan sekitar, juga dapat mengedukasi masyarakat untuk mengenal lebih dalam mengenai tumbuhan penghasil warna yang dapat dipakai pada proses pewarnaan kain. Zona penanaman dibagi menjadi 2 , tanaman yang berbatang besar akan ditanan pada lantai dasar behubung dengan ukuran dan akar yang besar. Sedangkan tanaman tak berkayu dan umbi-umbian ditanam pada atap menggunakan sisten agro fabric, sehinga panas cahaya matahari dapat diatur.

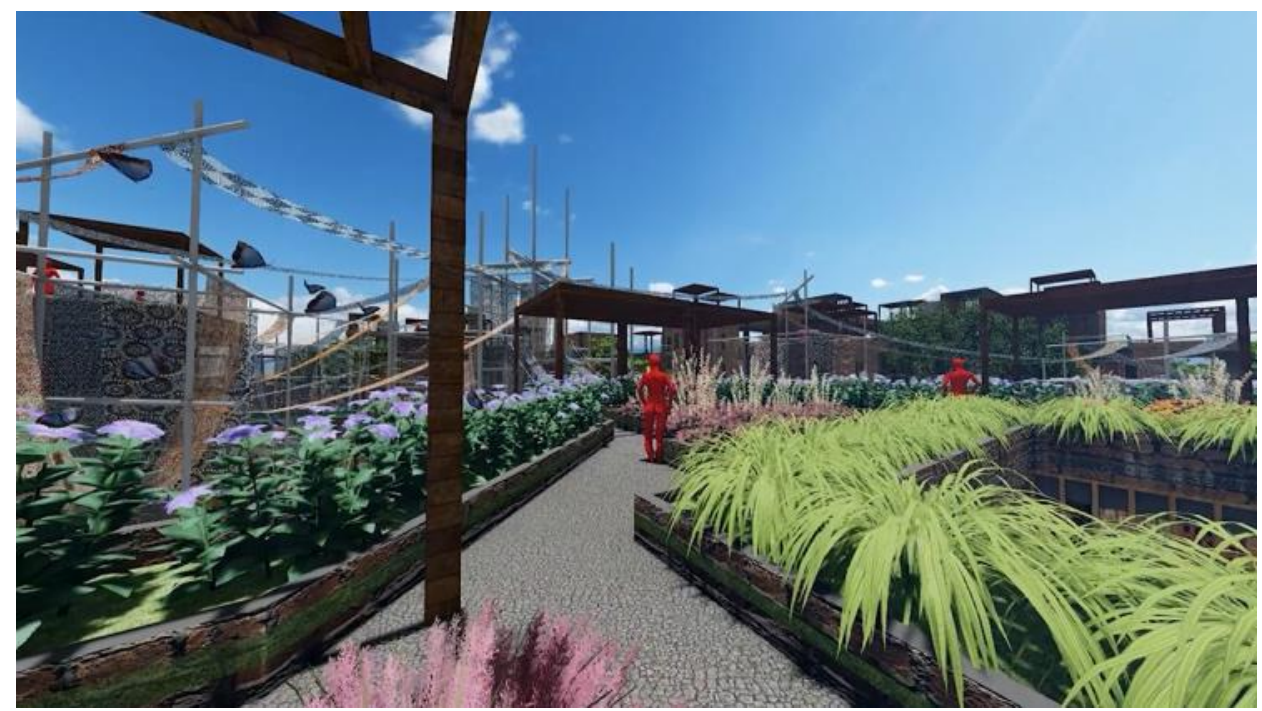

Gambar 10. Roof Garden

Sumber: Penulis, 2019 


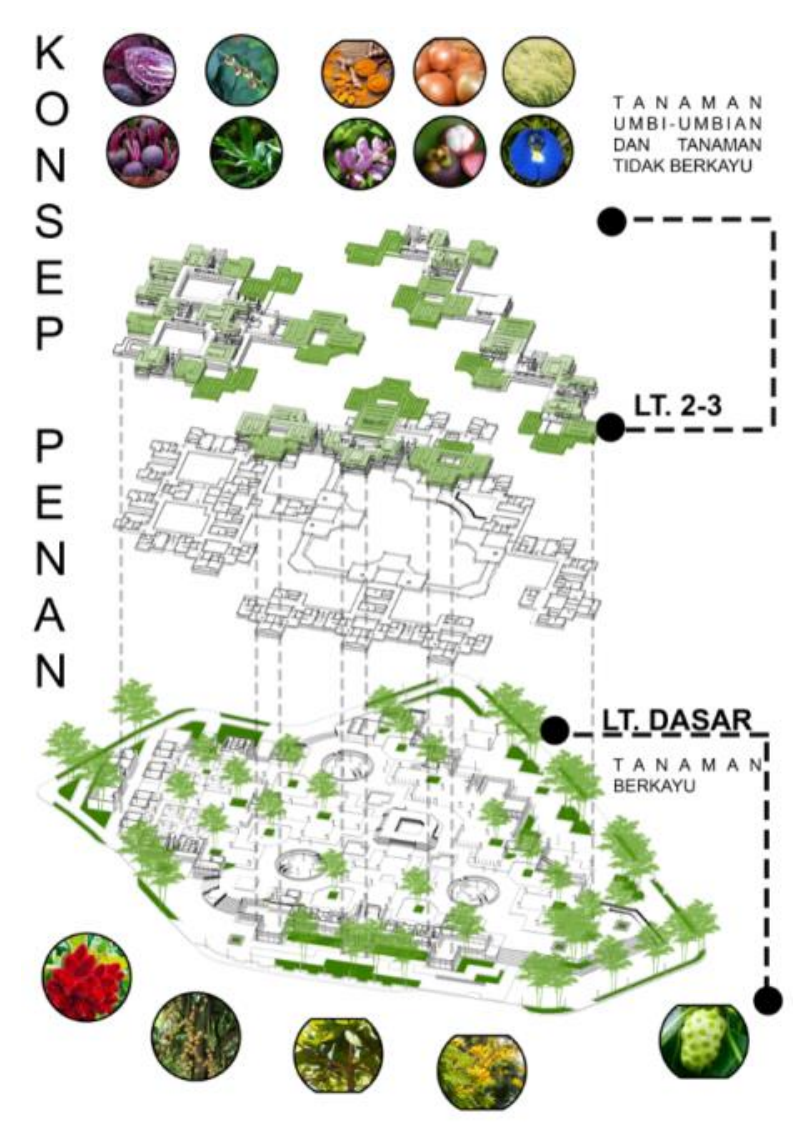

Gambar 11. Sistem Penanaman

Sumber: Penulis, 2019

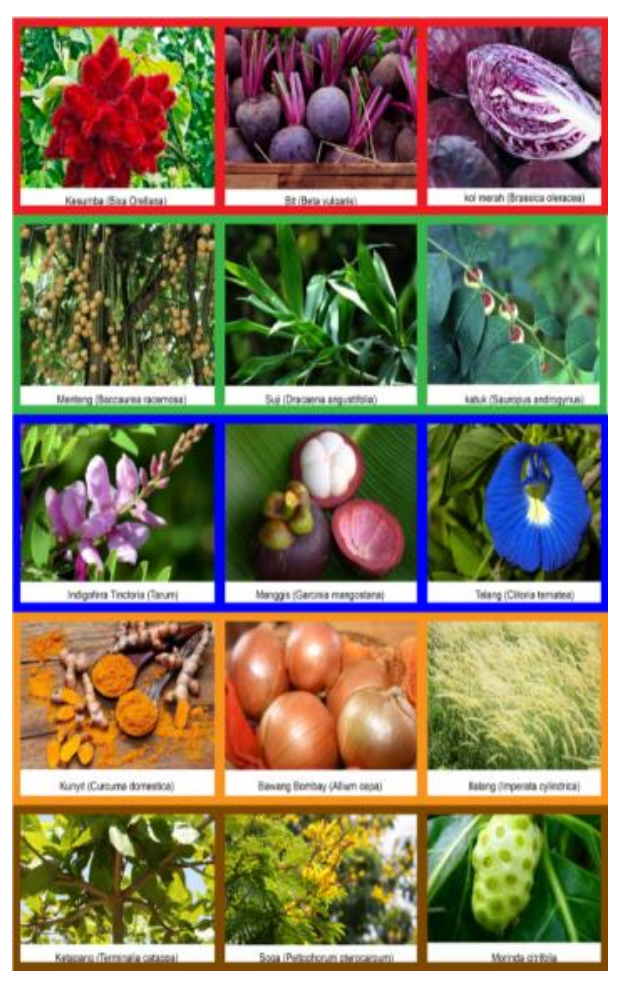

Gambar 12. Sayuran Berwarna Sumber: Penulis, 2019 


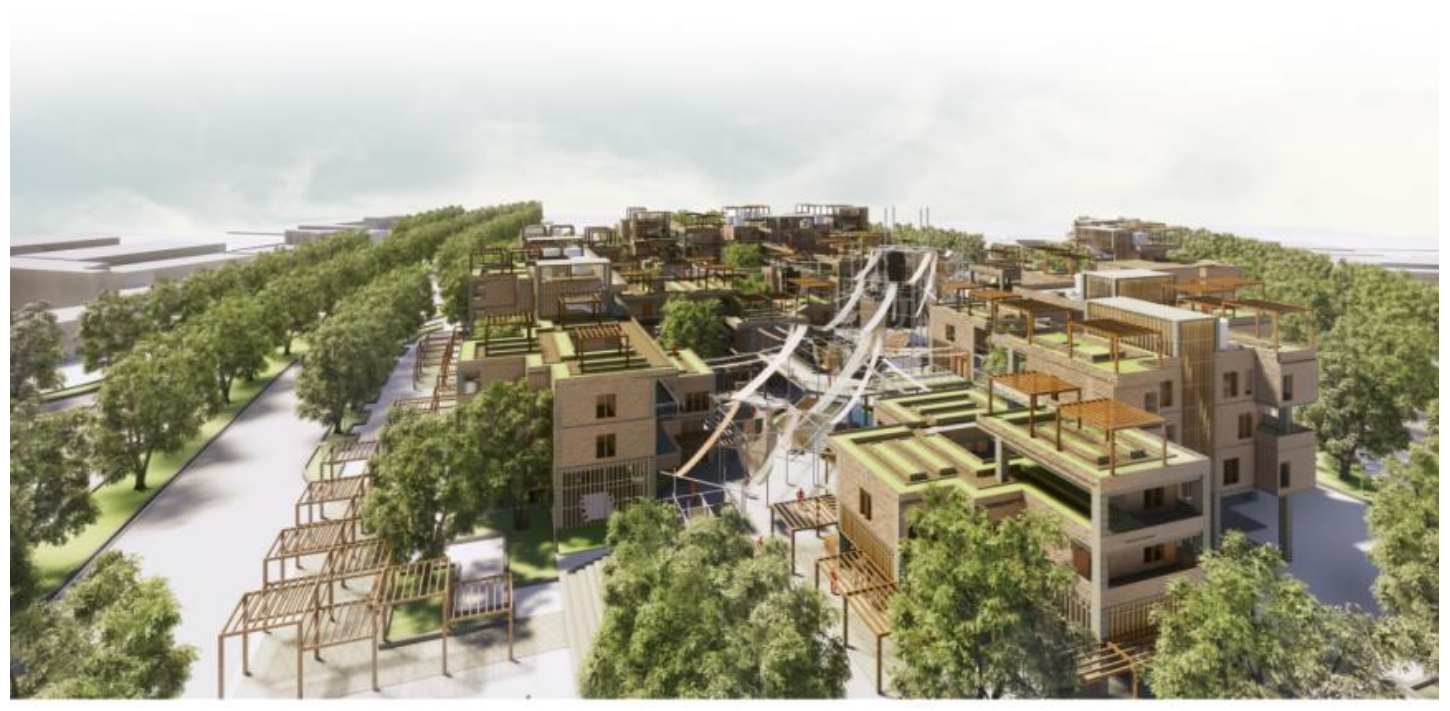

Gambar 13. Gambar Perspektif Eksterior Kampung Batik Sumber: Penulis, 2019

\section{KESIMPULAN DAN SARAN}

\section{Kesimpulan}

Jakarta merupakan kota besar yang terdiri dari berbagai macam perkampungan yang tersebar luas. Masing-masing dari kampung tersebut memiliki sejarah dan ceritanya yang unik. Namun seiring dengan perkembanga zaman kurangnya perhatian pemerintah dan tingkat edukasi masyarakat membuat identitas dari kampung-kampung tersebut hilang ditelan zaman. Hilangnya identitas suatu kampung membuat warga kampung semakin terbelakang, ditambah lagi dengan pesatnya pertumbuhan penduduk yang semakin meningkat membuat permukiman di perkampungan semakin kumuh dan tidak layak huni. Hal inilah yang membuat kata perkampungan sering dikaitakan dengan daerah miskin. Oleh karena itu perlu adanya peremajaan kembali kampung-kampung di Kota Jakarta.

Peremajaan kembali suatu kampung di perkotaan khususny Jakarta tidak hanya sekedar menggantikannya menjadi rumah susun dengan standar kelayakan yang baik, namun perlu juga diperhatikan sejarah perkembangan kegiatan di kawasan kampung tersebut, agar keunikan dan identitas dari kampung itu tidak hilang dan dapat dijadikan sebagai peluang ekonomi warga. Program Kampung Batik merupakan bentuk peremajaan kembali kampung di kawasan Karet Kuningan dengan mengangkat batik sebagai ciri khas dan identitas kegiatan di kawasan tersebut. Tidak hanya sekedar hunian, program ini juga memberikan pelatihan kepada warga untuk memulai usaha dari pembuatan kain batik hingga hasil olahan kain yang nantinya akan diperdagangkan. Terlepas dari itu, program ini akan menjadikan kampung tidak hanya berfungsi sebagai hunian, namun juga bisa menunjang edukasi, perekonomian, dan pusat destinasi wisata di daerah tersebut.

\section{Saran}

Oleh karena itu perlu adanya perhatian khusus baik dari pihak pemerintah maupun masyarakat setempat untuk sadar akan pentingnya ciri khas dan identitas kampung dalam menghidupkan kembali kehidupan perkampungan perkotaan khususnya di ibukota Jakarta. Sebab dari ciri khas itulah sebuah perkampungan dapat mewakili warganya untuk dapat bersaing dan bisa menjadi roda perekonomian di kawasan tersebut. 


\section{REFERENSI}

Archnet-IJAR. (2016). Volume 10 - Issue 1 - March 2016 - (195-212) - Regular Section

Belfield, C., dkk. (2016).Middle income families receiving more benefits and increasingly living in rented housing. London: Institute for Fiscal Studies,

Biro Pusat Statistik. (1997). Indikator Kesejahteraan Sosial. -------, 1980, 1985, 1995, 1997, 1998, Statistik Tahunan Indonesia. Depnaker, 1997, Direktorat Informasi Pasar Kerja.

CBRE. (2016). Wellness in the Workplace: Unlocking Future Performance [online], available at: http://www.cbre.eu/emea_en/services/wellnessinthe workplace

Chase, J., dkk. (1999). Everyday Urbanism. New York: Monacal Press. ISBN 1885254814.

Deloitte. (2016). The Deloitte Millennial Survey [online], available at: http:// www2.deloitte.com/global/en/pages/about-deloitte/articles/millennialsurvey.html

Elshater, A. (2015). The Principles of Gestalt Laws and Everyday Urbanism. Illinois, USA: Common Ground Publishing LLC.

Haagen, S., dkk. (2014). Narrow Dwellings. Lund School of Architecture

Juwono, S. dan Asnawie, H.W. (2005). Mengungkap Sejarah Kampung Kuningan. Diterbitkan pada kalangan sendiri.

Juwono, S. (2005). Prosiding Seminar Internasional Urban Conservation Universitas Trisakti dan Universitas Tokyo. In Explore of Urban Value in Historical Urban Kampung in Jakarta. Case of Kampung Kuningan.

Lintang, N., G.M. (2018). Kota Yang Terbelah. Diunduh 17 Januari 2018. http://kampungkota.net/2018/01/17/kota-yang-terbelah/

Mardiastuti, A. (2016). Manfaatkan Bahan Alami, Pengusaha Batik Ini Raup Omzet Rp 7 Juta/Bulan. Diunduh 28 September 2016. https://finance.detik.com/solusiukm/d3309135/manfaatkan-bahan-alami-pengusaha-batik-ini-raup-omzet-rp-7-jutabulan

Obatrindu (2016). Macam-Macam Bahan Pewarna Alami Kain Batik dari Tumbuhan. Diundih 8 November 2016. https://obatrindu.com/bahan-pewarna-alami-batik/

Parmono, K. (1995). Simbolisme Batik Tradisional.

Pransiska, L. (2016). Luwes Menyerap Perubahan Zaman. Diunduh 22 Agustus 2016. https://batik.kompas.id/jakarta-papua/luwes-menyerap-perubahan-zaman

Setia, K. U. (2016). Mengenal Tumbuhan Jitu Penghasil Warna Tekstil. Diunduh 3 Maret 2016. https://www.liputan6.com/lifestyle/read/2450249/mengenal-tumbuhan-jitu-penghasilwarna-tekstil?related=dable\&utm_expid=.9Z4i5ypGQeGiS7w9arwTvQ.1\&utm_referrer=

Vink, G. A., dkk. (2013). City>Block>House. Aalborg University

Walters, D. (2007). Designan community: charranes, master plans and form-based podes. Oxford: Architectural Press. pp. 135-159.

Yuwono, S. dan Wardiningsih, S. (2016). Mempertahankan Keberadaan Kampung di TengahTengah Kawasan Modern Jakarta. Jakarta: Jurnal Arsitektur NALARs Volume 15 No 1 Januari 2016:73-80 